Dorothee M. Gaumann MD, * Edömer Tassonyi MD, * Robert W. Rivest PhD, $\dagger$ Marc Fathi PhD, $\ddagger$ Alain F. Reverdin MD§

\section{Cardiovascular and endocrine effects of clonidine premedica- tion in neurosurgical patients}

Plasma glucose concentrations increased in both groups at the end of the study $(P<0.05)$, but were lower in clonidine-treated patients $(P<0.05)$. Though statistically significant, the observed inhibitory haemodynamic and endocrine effects of clonidine seem to be of minor clinical importance. As the action of clonidine on cerebral bloodflow regulation is not well known, we see no advantage in the preanaesthetic administration of clonidine to neurosurgical patients with normal cardiovascular status.

Cette étude fut conduite afin d'examiner les effets hémodynamiques et endocriniens de la clonidine administrée comme seule prémédication chez les patients neurochirurgicaux. Dixneuf patients ASA classe I et II, devant subir une craniotomie, furent randomisés afin de recevoir une prémédication orale soit de clonidine (300 $\mu \mathrm{g}, n=9)$ ou un placebo $(n=10)$. La pression artérielle et la fréquence cardiaque furent surveillées continuellement alors que des échantillons sanguins furent prélevés à des temps précis à partir de l'induction de l'anesthésie jusqu'au réveil pour la mesure des concentrations plasmatiques d'épinéphrine, norépinéphrine, cortisol, aldostérone et glucose. Le traitement à la clonidine a amené une diminution dans la pression artérielle moyenne (PAM), la fréquence cardiaque (FR), et les concentrations plasmatiques de cortisol et d'aldostérone à travers l'étude comparativement au placebo $(P<0.05)$. La clonidine, cependant, n'a pas empêché l'augmentation de la PAM (16 $\pm 5 \mathrm{mmHg}$, moyenne $\pm S E, P<0.05)$ et $F R(18 \pm 4 \mathrm{bpm}, P<0.05)$ lors de l'induction de l'anesthésie fut comparable au groupe placebo. Les concentrations plasmatiques de catécholamines n'étaient pas différentes entre les deux groupes. Les concentrations plasmatiques de glucose ont augmenté dans les deux groupes à la fin de l'étude $(P<0.05)$ mais étaient moindres chez les patients traités à la clonidine $(P<0.05)$. Même si statistiquement significatifs, les effets hémodynamiques et endocriniens de la clonidine semblent avoir une importance clinique mineure. Etant donné que l' action de la clonidine sur la régulation du flux sanguin cérébral n'est pas connue, on ne voit aucun avantage dans l'administration pré-anesthésique de la clonidine chez les patients neurochirurgicaux avec un état cardiovasculaire normal. 
Clonidine, an antihypertensive drug which acts preferentially as an agonist at alpha ${ }_{2}$-adrenergic receptors, ${ }^{1}$ has gained increasing propularity in anaesthetic practice over the last few years. It has been used as an adjuvant to general anaesthesia because of its central analgesic, sedative, and sympathetic inhibitory effects, ${ }^{2-4}$ which may be beneficial in patients with cardiovascular compromise. Clonidine, administered as an oral preanaesthetic medication, blunts the increase in blood pressure, heart rate and intraocular pressure, associated with laryngoscopy and tracheal intubation in hypertensive and elderly patients, ${ }^{5-7}$ and provides increased haemodynamic stability and decreased adrenergic activity during the intra- and postoperative periods. At the same time, the requirement for anaesthetic and opioid administration is reduced..$^{5-9}$ Before general recommendations about the usefulness of clonidine preanaesthetic medication can be established, more clinical studies are required which examine the effects of clonidine in different patient populations and different surgical settings. ${ }^{10}$ As maintenance of haemodynamic stability and avoidance of hypertensive episodes is important in patients with intracranial pathology, ${ }^{11}$ clonidine might be a useful adjunct to general anaesthesia for neurosurgery. The present study examined the haemodynamic, adrenergic and adrenal cortical responses in neurosurgical patients, in order to evaluate the effects of clonidine on the overall stress response associated with craniotomy.

\section{Methods}

The study was conducted after approval by the local ethics committee for clinical research, and after having obtained informed consent. Nineteen normotensive patients (ASA physical status I and II), scheduled for elective craniotomy as the first cases in the morning, were included in the study which was conducted in a randomized, double-blind fashion. Exclusion criteria for the study were: steroid medication for more than three days, clinical signs of increased intracranial pressure, chronic medication interfering with blood pressure regulation, diabetes mellitus and pituitary or hypothalamic tumours.

Two groups of patients were examined: Group $\mathrm{C}(n=$ 9) received $300 \mu \mathrm{g}$ clonidine po, 60-90 min before induction of anaesthesia, while patients in Group $\mathrm{P}(n=$ 10) received placebo. On arrival in the anaesthesia induction room, a peripheral venous catheter and a radial arterial catheter were inserted. Heart rate (HR) was monitored continuously via a three-lead ECG. After a ten-minute resting period, a baseline arterial blood sample was taken and haemodynamic variables were recorded. Anaesthesia was induced using thiopentone at a dose of 5 $\mathrm{mg} \cdot \mathrm{kg}^{-1} i v$. After loss of the eyelid reflex, ventilation was begun by face mask with $1.5 \%$ isoflurane in oxygen. Vecuronium bromide $\left(0.1 \mathrm{mg} \cdot \mathrm{kg}^{-1} i v\right)$ was then adminis- tered and mask ventilation was continued for three minutes with $1.5 \%$ isoflurane in oxygen, before endotracheal intubation was performed. Thereafter, all patients were monitored using an oesophageal stethoscope, a central venous line, a rectal temperature probe, and a urinary catheter. The patient's lungs were mechanically ventilated and anaesthesia was maintained with $\mathrm{O}_{2} / \mathrm{N}_{2} \mathrm{O}$ and isoflurane. The end-tidal concentrations of isoflurane, $\mathrm{N}_{2} \mathrm{O}$ and $\mathrm{CO}_{2}$ were measured continuously by a multiple gas analyzer (Capnomac, Datex). Hyperventilation $\left(\mathrm{ETCO}_{2}: 4 \pm 0.5 \%\right)$ was maintained throughout anaesthesia, and end-tidal $\mathrm{CO}_{2}$ values were confirmed intermittently by arterial blood gas analysis. The endtidal $\mathrm{N}_{2} \mathrm{O}$ concentration was kept at $65 \%$ throughout the operation, whereas isoflurane was administered as required to maintain mean arterial blood pressure (MABP) close to preinduction values. Supplemental doses of vecuronium were given when necessary. Anaesthetic gases were discontinued after termination of surgery. The tracheas were extubated when patients responded to commands.

Arterial blood samples were taken at specific times of the study, for the measurement of plasma concentrations of catecholamines, cortisol, aldosterone, and glucose. The baseline sample $S 1$ was collected before induction of anaesthesia; sample S2 was collected two minutes after intubation; sample $\mathbf{3}$ during opening of the skull; sample S4, 60 min after collection of sample S3; sample S5 during skin closure; sample S6, 2 min after extubation; and sample S7, $30 \mathrm{~min}$ after extubation in the recovery room. Catecholamines in plasma were analyzed by high-performance liquid chromatography with electrochemical detection. The inter-assay variability was $9 \%$ and the intra-assay variability was $7 \%$. The assay sensitivity for norepinephrine was $15 \mathrm{pg}$ /injection on the column, and for epinephrine $20 \mathrm{pg}$ /injection on the column. ${ }^{12}$ Cortisol was measured by a transcortine binding assay, which shows a sensitivity of $30 \mathrm{nmol} \cdot \mathrm{L}^{-1} \cdot{ }^{13}$ Aldosterone was analyzed by a radioimmunoassay which has a sensitivity of $0.04 \mathrm{nmol} \cdot \mathrm{L}^{-1}$ (Diagnostic Products Co., Los Angeles).

Statistical analysis of group differences concerning patient characteristics were analyzed by unpaired $t$ test for continuous variables, and for discrete data by the chisquare test. The MABP, HR, plasma hormone and glucose concentrations at the different times of the study were analyzed by a two-way analysis of variance with repeated measures over time, to assess differences due to treatment and time of sampling. An a posteriori contrast analysis was employed to compare specific sampling times.* If a significant group by time interaction was

*SPSS User's Guide, second edition. SPSS Inc. Chicago Il $60611,1986$. 
TABLE I Patients' characteristics

\begin{tabular}{|c|c|c|}
\hline & $\begin{array}{l}\text { Clonidine } \\
(n=9)\end{array}$ & $\begin{array}{l}\text { Placebo } \\
(n=10)\end{array}$ \\
\hline Age (yr) & $50( \pm 6)$ & $48( \pm 5)$ \\
\hline Weight $(\mathrm{kg})$ & $65( \pm 4)$ & $68( \pm 5)$ \\
\hline Duration of surgery $(\mathrm{min})$ & $166( \pm 41)$ & $211( \pm 25)$ \\
\hline \multicolumn{3}{|l|}{ Type of surgery (n) } \\
\hline abscess & - & 1 \\
\hline cranioplasty & 1 & 2 \\
\hline meningioma & - & 4 \\
\hline posterior fossa & 2 & 1 \\
\hline tumour & 4 & - \\
\hline vascular surgery & 2 & 2 \\
\hline$i v$ Fluids $\left(\mathrm{ml}^{-} \cdot \mathrm{hr}^{-1}\right)$ & $\begin{array}{l}483 \\
( \pm 83)\end{array}$ & $\begin{array}{l}457 \\
( \pm 83)\end{array}$ \\
\hline Urine $(\mathrm{ml})$ & $\begin{array}{l}730 \\
( \pm 200)\end{array}$ & $\begin{array}{l}780 \\
( \pm 80)\end{array}$ \\
\hline
\end{tabular}

Values expressed as mean $\pm \mathrm{SE}, n=$ number of patients.

TABLE II Isoflurane administration during surgery

\begin{tabular}{lllll}
\hline & Group & $S 3$ & $S 4$ & $S 5$ \\
\hline Isoflurane & Clonidine & 0.63 & $0.53^{*}$ & $0.50^{*}$ \\
$(\%)$ & & $( \pm 0.05)$ & $( \pm 0.05)$ & $( \pm 0.07)$ \\
& Placebo & 0.74 & 0.72 & 0.66 \\
& & $( \pm 0.05)$ & $( \pm 0.04)$ & $( \pm 0.03)$ \\
\hline
\end{tabular}

End-expiratory isoflurane concentrations (mean $\pm S E$ ) at the different times of surgery: $S 3=$ beginning of craniotomy; $S 4=60 \mathrm{~min}$ after S3; S5 = end of surgery, in patients with preanaesthetic mediation of clonidine $(300 \mu \mathrm{g} p o, n=9)$ or placebo $(n=10) .{ }^{*} P<0.05$ between group comparison.

detected by analysis of variance, as in the case of glucose levels, a Duncan multiple range test was employed to identify the times when values were different. In all tests, $P<0.05$ was considered significant.

\section{Results}

Patients in the two groups were not different with regard to demographic data, duration and type of surgery, body temperature, fluid administration and diuresis (Table I).

During surgery $(\mathrm{S} 4, \mathrm{~S} 5)$, patients treated with clonidine required lower isoflurane concentrations than placebotreated patients (Table II). However, the overall anaesthetic requirement (isoflurane $+65 \% \mathrm{~N}_{2} \mathrm{O}$ ) was low in both groups, ranging on an average from 1.05-1.17 MAC in patients who had received clonidine and from 1.19-1.26 MAC in patients who had received placebo.

Patients treated with clonidine had lower MABP and HR values throughout the study than patients treated with placebo (Figures 1 and 2). However, changes in MABP observed during the study were not different between the



FIGURE 1 Mean arterial blood pressure (MABP) in patients after preanaesthetic medication of clonidine $(300 \mu \mathrm{g} p o, n=9 ;-0)$ or placebo $(n=10 ;-O-)$ at the different times of the study: $\mathrm{S} 1=$ baseline; $\mathrm{S} 2=2 \mathrm{~min}$ after intubation; $\mathrm{S} 3=$ beginning of craniotomy; $\mathrm{S} 4=60 \mathrm{~min}$ after S3; S5 = end of surgery; $\mathrm{S} 6=2 \mathrm{~min}$ after extubation; $\mathrm{S} 7=30 \mathrm{~min}$ after $\mathrm{S} 6$ (mean $\pm \mathrm{SE}$ ). ${ }^{*} P<0.05$ compared with $\mathrm{S} 1 ;{ }^{* *} P<0.05$ compared with $\mathrm{S} 2$ and $\mathrm{S} 6$ and $\mathrm{S} 7$;

$\dagger P<0.05$ between group comparison.

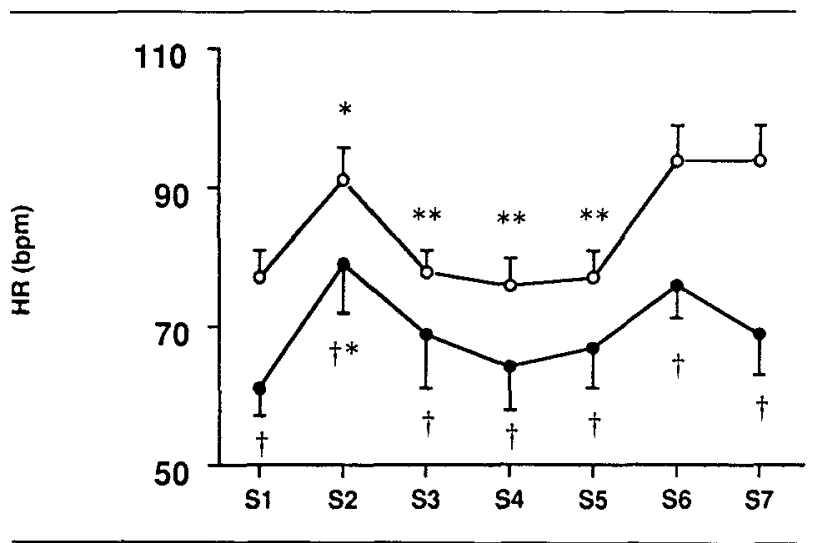

FIGURE 2 Heart rate (HR) in patients after preanaesthetic medication of clonidine $(300 \mu \mathrm{g} p o, n=9 ;-)$ ) or placebo $(n=10$; $-O-)$ during the different times of the study as in Fig. 1. $* P<0.05$ compared with $\mathrm{S} 1$; $* * P<0.05$ compared with $\mathrm{S} 2$ and $\mathrm{S} 6$ and $\mathrm{S} 7 ; \uparrow P<0.05$ between group comparison.

two groups. Thus, following intubation (S2) both groups showed an increase in MABP compared with baseline (Group C: $16 \pm 5 \mathrm{mmHg}$; Group P: $23 \pm 7 \mathrm{mmHg}$, mean $\pm \mathrm{SE}, P<0.05$ ). During surgery (S3-S5), both groups showed a decrease in MABP compared with intubation, extubation and early recovery $(P<0.05)$. Both groups had an increase in HR following intubation compared with baseline (Group C: $18 \pm 4$ bpm; Group P: $14 \pm 3$ bpm, $P<0.05$ ). In patients treated with placebo, HR decreased during surgery (S3-S5), compared with the intubation and post-extubation period $(P<0.05)$, while in patients treated with clonidine, HR during surgery was 
TABLE III Plasma concentrations of catecholamines, cortisol, aldosterone and glucose during the study

\begin{tabular}{|c|c|c|c|c|c|c|c|c|}
\hline & Group & $S I$ & $S 2$ & $s 3$ & $S 4$ & S5 & S6 & $S 7$ \\
\hline $\begin{array}{l}\mathrm{NE} \\
\left(\mathrm{nmol} \cdot \mathrm{L}^{-1}\right)\end{array}$ & $\begin{array}{l}\text { Clonidine } \\
\text { Placebo }\end{array}$ & $\begin{array}{l}2.34 \\
( \pm 1.10) \\
2.10 \\
( \pm 0.54)\end{array}$ & $\begin{array}{l}2.12 \\
( \pm 0.89) \\
2.78 \\
( \pm 0.67)\end{array}$ & $\begin{array}{l}2.19 \\
( \pm 0.81) \\
2.46 \\
( \pm 0.65)\end{array}$ & $\begin{array}{l}2.30 \\
( \pm 0.90) \\
2.54 \\
( \pm 0.62)\end{array}$ & $\begin{array}{l}1.91 \\
( \pm 0.81) \\
2.46 \\
( \pm 0.48)\end{array}$ & $\begin{array}{l}2.01 \\
( \pm 0.97) \\
2.81 \\
( \pm 0.50)\end{array}$ & $\begin{array}{l}2.01 \\
( \pm 0.93) \\
3.51 \\
( \pm 0.76)\end{array}$ \\
\hline $\begin{array}{l}\text { EPI } \\
\left(\mathrm{nmol} \cdot \mathrm{L}^{-1}\right)\end{array}$ & $\begin{array}{l}\text { Clonidine } \\
\text { Placebo }\end{array}$ & $\begin{array}{l}0.36 \\
( \pm 0.14) \\
0.39 \\
( \pm 0.09)\end{array}$ & $\begin{array}{l}0.22 \\
( \pm 0.07) \\
0.37 \\
( \pm 0.10)\end{array}$ & $\begin{array}{l}0.32 \\
( \pm 0.13) \\
0.36 \\
( \pm 0.07)\end{array}$ & $\begin{array}{l}0.32 \\
( \pm 0.10) \\
0.36 \\
( \pm 0.09)\end{array}$ & $\begin{array}{l}0.32 \\
( \pm 0.10) \\
0.42 \\
( \pm 0.09)\end{array}$ & $\begin{array}{l}0.41 \\
( \pm 0.17) \\
0.46 \\
( \pm 0.08)\end{array}$ & $\begin{array}{l}0.41 \\
( \pm 0.19) \\
0.60 \\
( \pm 0.18)\end{array}$ \\
\hline $\begin{array}{l}\text { Cortisol } \\
\left(\mathrm{nmol} \cdot \mathrm{L}^{-1}\right)\end{array}$ & $\begin{array}{l}\text { Clonidine } \\
\text { Placebo }\end{array}$ & $\begin{array}{l}288 \ddagger \\
( \pm 125) \\
737 \\
( \pm 166)\end{array}$ & $\begin{array}{l}212 \ddagger \\
( \pm 64.5) \\
733 \\
( \pm 163)\end{array}$ & $\begin{array}{l}153 \div \dagger \\
( \pm 35.4) \\
643 \dagger \\
( \pm 125)\end{array}$ & $\begin{array}{l}230 \ddagger \\
( \pm 87.2) \\
658 \\
( \pm 68.6)\end{array}$ & $\begin{array}{l}413 \ddagger \\
( \pm 136) \\
884 \\
( \pm 59.7)\end{array}$ & $\begin{array}{l}520 \ddagger \\
( \pm 160) \\
990 \\
( \pm 90.3)\end{array}$ & $\begin{array}{l}740 \ddagger \\
( \pm 177) \\
1243 \\
( \pm 124)\end{array}$ \\
\hline $\begin{array}{l}\text { Aldosterone } \\
\left(\mathrm{nmol} \cdot \mathrm{L}^{-1}\right)\end{array}$ & $\begin{array}{l}\text { Clonidine } \\
\text { Placebo }\end{array}$ & $\begin{array}{l}0.23 \ddagger \\
( \pm 0.09) \\
0.40 \\
( \pm 0.08)\end{array}$ & $\begin{array}{l}0.19 \ddagger \\
( \pm 0.05) \\
0.32 \\
( \pm 0.07)\end{array}$ & $\begin{array}{l}0.21 \ddagger \\
( \pm 0.05) \\
0.43 \\
( \pm 0.08)\end{array}$ & $\begin{array}{l}0.32 \ddagger \\
( \pm 0.12) \\
0.55 \\
( \pm 0.10)\end{array}$ & $\begin{array}{l}0.33 \ddagger \\
( \pm 0.10) \\
0.66 \\
( \pm 0.11)\end{array}$ & $\begin{array}{l}0.44 \ddagger \\
( \pm 0.10) \\
0.84 \\
( \pm 0.14)\end{array}$ & $\begin{array}{l}0.58 \dagger * \\
( \pm 0.20) \\
0.93 \\
( \pm 0.14)^{*}\end{array}$ \\
\hline $\begin{array}{l}\text { Glucose } \\
\left(\mathrm{nmol} \cdot \mathrm{L}^{-1}\right)\end{array}$ & $\begin{array}{l}\text { Clonidine } \\
\text { Placebo }\end{array}$ & $\begin{array}{l}6.13 \\
( \pm 0.20) \\
5.76 \\
( \pm 0.44)\end{array}$ & $\begin{array}{l}5.93 \\
( \pm 0.23) \\
5.83 \\
( \pm 0.44)\end{array}$ & $\begin{array}{l}6.98 \\
( \pm 0.24) \\
6.37 \\
( \pm 0.24)\end{array}$ & $\begin{array}{l}6.62 \\
( \pm 0.31) \\
6.56 \\
( \pm 0.25)\end{array}$ & $\begin{array}{l}6.52 \\
( \pm 0.30) \\
7.58^{*} \\
( \pm 0.34)\end{array}$ & $\begin{array}{l}6.71 \ddagger \\
( \pm 0.28) \\
8.29^{*} \\
( \pm 0.40)\end{array}$ & $\begin{array}{l}7.06^{+*} \\
( \pm 0.30) \\
9.04^{*} \\
( \pm 0.39)\end{array}$ \\
\hline
\end{tabular}

Plasma concentrations of norepinephrine (NE) and epinephrine (EPI), cortisol, aldosterone, and glucose in patients with preanaesthetic medication of clonidine ( $300 \mu \mathrm{g} \mathrm{po,n=9)}$ or placebo $(n=10)$ at the different times of the study: $\mathrm{S} 1$ = baseline; $\mathrm{S} 2=2 \mathrm{~min}$ after intubation;

$\mathrm{S} 3=$ beginning of craniotomy; $\mathrm{S} 4=60 \mathrm{~min}$ after $\mathrm{S} 3 ; \mathrm{S} 5=$ end of surgery; $\mathrm{S} 6=2 \mathrm{~min}$ after extubation; $\mathrm{S} 7=30 \mathrm{~min}$ after $\mathrm{S} 6$

(mean $\pm \mathrm{SE}$ ). ${ }^{*} P<0.05$ compared with $\mathrm{S} 1$ and $\mathrm{S} 2,+P<0.05$ compared with $\mathrm{S} 1$ and $\mathrm{S} 6$ and $\mathrm{S} 7, \ddagger P<0.05$ between group comparison.

not different from values observed following intubation and extubation.

Plasma catecholamine concentrations were not different between groups and were within normal values throughout the study (Table III). Plasma cortisol concentrations were lower throughout the study in clonidinetreated patients than in patients receiving placebo $(P<$ 0.05 , Table III). A trough in cortisol levels was observed during surgery (S3) in both groups, compared with baseline and the post-extubation period $(P<0.05)$. Clonidine premedication caused a decrease in aldosterone concentrations throughout the study, as compared to placebo ( $P<0.05$, Table III). In both groups, aldosterone concentrations increased during recovery (S7) compared with the beginning of the study (S1, S2; $P<0.05$ ). Blood glucose concentrations (Table III) were not different in the two groups from baseline until the end of surgery (S5). Differences between the two groups occurred following extubation (S6, S7), when higher glucose concentrations were observed in placebo-treated patients $(P<0.05)$. An increase in glucose concentration compared with baseline was observed in placebo-treated patients from skin closure to recovery (S5-S7), while clonidine-treated patients had increased glucose concentrations only during the recovery period (S7).

\section{Discussion}

Hypotensive and bradycardic effects of clonidine are mediated by action at the alpha $a_{2}$-receptors, located in brain stem cardiovascular centres which leads to inhibition of sympathetic outflow and stimulation of vagal efferents. ${ }^{4}$ In the present study, patients treated with clonidine had lower values of MABP and HR, from the pre-induction to the early post-anaesthesia recovery period, than patients who had received placebo. This indicates that the dose and timing of preanaesthetic clonidine medication were appropriate. In normotensive subjects, clonidine leads to a decrease in blood pressure of more than $10 \mathrm{mmHg}$ from $60 \mathrm{~min}$ to more than eight hours after po administration. This corresponds to clonidine plasma concentrations reaching a peak at $90 \mathrm{~min}$ and having a half-life of eight hours. ${ }^{14,15}$ Due to the long action of clonidine, which generally exceeds the time of surgery, amelioration of postoperative hypertension has been proposed. ${ }^{10}$ Though clonidine decreased MABP and HR throughout the study by approximately $10 \mathrm{mmHg}$ and 15 bpm compared with placebo, these differences between the two groups are probably not of great clinical importance, especially in patients with a normal cardiovascular system. Clonidine treatment did not prevent increases in $\mathrm{MABP}$ and HR following tracheal intubation, and MABP 
and HR curves generally ran parallel in clonidine- and placebo-treated patients. As anaesthesia induction was standardized in all patients, using 1.5\% of isoflurane, increased MABP and HR observed in clonidine-treated patients following intubation cannot be attributed to differences in anaesthetic depth. Our results correspond to a recent study conducted in patients of ASA physical status I and II, in whom the hyperdynamic response to laryngoscopy was not blunted by clonidine premedication $(200 \mu \mathrm{g} \mathrm{po}) .{ }^{16}$ The difference between our study and five major studies which reported increased haemodynamic stability with clonidine premedication, ${ }^{5-9}$ consists in the patient population and study design, while the dose of clonidine and timing of administration were comparable. All of these studies included hypertensive and mainly elderly patients, who were often receiving multiple antihypertensive and antianginal drugs. This did not allow the identification of effects solely mediated by clonidine, as drug interactions might have had occurred. ${ }^{10}$ Further, only two of these studies had been conducted in a double-blind fashion. ${ }^{7,9}$ In our study, we tried to identify purely clonidine-mediated effects by comparing clonidine with placebo and by avoiding multiple drug interactions. The risk of inadvertently unblinding the study due to prominent effects of clonidine did not exist in the present study. During the preanaesthesia induction period patients were generally calm and routine observation did not allow identification of patients who had received clonidine. As discussed, the haemodynamic and anaesthetic sparing effects of clonidine were not important enough to unblind the investigators. Comparison of our results with those of previous studies may indicate that clonidine preanaesthetic medication is more beneficial in elderly patients receiving antihypertensive medication, than in younger patients without cardiovascular problems. The difference in patients' responses to clonidine may be due to altered sympathetic responsiveness in elderly patients, ${ }^{17}$ as well as to the potentiating effects of clonidine, when co-administered with other antihypertensive drugs. ${ }^{15}$

In both treatment groups, plasma catecholamine concentrations were in the range of normal values, indicating that the standard anaesthesia employed provided sufficient endocrine stability even in the placebo group.

Compared with placebo, clonidine led to decreased plasma cortisol concentrations throughout the study, probably due to an inhibitory effect on pituitary ACTH secretion. ${ }^{18}$ The suppression of cortisol secretion is not likely to present any risks, as cortisol concentrations were generally within the range of normal values, and secretory reactivity was preserved in all patients. A trough in cortisol levels occurred in both treatment groups during surgery, probably reflecting the central depressant effects of general anaesthesia. ${ }^{19}$
Plasma aldosterone concentrations are regulated via plasma renin activity, which is highly dependent on sympathetic stimulation, as well as on ACTH secretion. ${ }^{20}$ Thus, probably due to the inhibitory effects of clonidine on these two components, aldosterone concentrations were decreased in clonidine-treated patients compared with control. Increases in aldosterone concentrations, observed during the recovery period in both groups, indicate a definite role of aldosterone in the endocrine response to surgery. ${ }^{19,20} \mathrm{~A}$ suppression of mineralocorticoid activity, resulting from decreased aldosterone and, to some degree, cortisol plasma concentrations, might present a certain advantage in neurosurgical patients, by decreasing sodium and water retention and thus limiting the risks of cerebral oedema. ${ }^{21}$ However, in view of the potent dehydrating effects of commonly used loop and osmotic diuretics, the clonidine-induced decrease in mineralocorticoid activity is probably of minor clinical importance.

Plasma glucose concentrations increased following surgery to a higher degree in patients treated with placebo than with clonidine. The increase in plasma glucose concentrations is probably the result of the stress-induced release of glucagon, epinephrine and cortisol which leads to increased glucose production and decreased glucose utilisation..$^{22}$ This indicates, in conjunction with observed aldosterone plasma concentrations and haemodynamic values, that the postoperative period following neurosurgery presents a stronger endocrine stimulus than surgery itself. Though clonidine treatment has been associated with hyperglycaemia via inhibition of insulin secretion, ${ }^{23}$ preanaesthetic medication with clonidine decreased blood glucose concentrations during the recovery period, compared with control. This indicates suppressant effects of clonidine on stress-induced hyperglycaemia and agrees with a report about the supressant effects of clonidine on excercise-induced hyperglycaemia. ${ }^{24}$ As hyperglycaemia has been associated recently with an increased risk of ischaemia-induced neuronal damage, the hyperglycaemia blunting effects of clonidine might be beneficial in neurosurgical patients. ${ }^{25}$ However, as ischaemic risks are highest during the intraoperative period, and as postoperative increases in blood glucose concentrations in control patients were below the values associated with an increased risk of neuronal damage, the benefit of clonidine medication in this regard may be limited.

Overall anaesthetic requirements (isoflurane $+65 \%$ $\mathrm{N}_{2} \mathrm{O}$ ) during the study were low in both groups, with values in the 1-1.3 MAC range. This may reflect a relatively small degree of nociceptive stimulation occurring with intracranial surgery. ${ }^{26}$ Patients who had received clonidine required lower isoflurane concentrations during surgery, maximally $0.16 \mathrm{MAC}$ less, than patients who 
had received placebo. The anaesthetic sparing effects of clonidine have been widely documented and are associated with decreased noradrenergic transmission in several brain areas. ${ }^{3}$ The lower anaesthetic levels obtained in clonidine-treated patients might have led to a slight underestimation of the endocrine and haemodynamic suppressant effects of clonidine, as adrenergic suppressant effects of inhalational anaesthetics have been reported to be dose-dependent. ${ }^{27}$ However, in a more recent clinical study, different levels of isoflurane $/ \mathrm{N}_{2} \mathrm{O}$ anaesthesia of 1.3 or $1.8 \mathrm{MAC}$ did not affect heart rate, blood pressure, and plasma cortisol and catecholamine concentrations to different degrees. ${ }^{28} \mathrm{We}$ believe that in the present study, isoflurane did not contribute to differences in haemodynamic and endocrine responses, observed between the two groups.

In conclusion, clonidine premedication caused a decrease in MABP, HR, plasma cortisol and aldosterone concentrations throughout the pre-, intra- and early postoperative periods. The effect of clonidine on these different variables is uniform, characterized by a suppression in baseline values and preservation of a normal pattern of haemodynamic and hormonal responses. Plasma glucose concentrations show a different response profile, with clonidine causing a blunted increase in glucose concentrations during the postoperative period compared with placebo. There is presently no evidence that the decreased hormone and glucose concentrations or haemodynamic values, as observed in the present study, influence the intraoperative course or postoperative recovery. As large changes in MABP and HR were not prevented, and in view of the fact that the action of clonidine on cerebral blood flow regulation is not well known, ${ }^{29}$ we see no advantage in the preanaesthetic administration of clonidine to neurosurgical patients with normal cardiovascular status.

\section{Acknowledgements}

We would like to thank Dr. A. Sautter from the Geneva University Hospital Pharmacy for preparing and coding the drugs, Ms. M. Lopez and Ms. L. Bockhorn for performing the cortisol and aldosterone assays and Ms. F. Iatropoulos for performing the catecholamine assays.

\section{References}

1 Jarrott B, Conway EL, Maccarrone C, Lewis SJ. Clonidine: understanding its disposition, sites and mechanism of action. Clin Exp Pharmacol Physiol 1987; 14: 471-9.

2 Lipman JJ, Spencer PSJ. Further evidence for a central site of action for the antinociceptive effects of clonidine-like drugs. Neuropharmacology 1979; 18: 731-3.

3 Maze $M$, Birch B, Vickery $R G$. Clonidine reduces halothane MAC in rats. (Letter) Anesthesiology 1987; 67: 868-9.
4 Unnerstall JR, Kopajtic TA, Kuhar MJ. Distribution of alpha $_{2}$-agonist binding sites in the rat and human central nervous system: analysis of some functional, anatomic correlates of the pharmacologic effects of clonidine and related adrenergic agents. Brain Res Rev 1984; 319 : 69-101.

5 Ghignone M, Quintin L, Duke PC, Kehler CH, Calvillo $O$. Effects of clonidine on narcotic requirements and hemodynamic response during induction of fentanyl anesthesia and endotracheal intubation. Anesthesiology 1986; 64: 36-42.

6 Ghignone $M$, Calvillo $O$, Quintin $L$. Anesthesia and hypertension: the effect of clonidine on perioperative hemodynamics and isoflurane requirements. Anesthesiology 1987; 67: 3-10.

7 Ghignone M, Noe C, Calvillo O, Quintin L. Anesthesia for ophthalmic surgery in the elderly: the effects of clonidine on intraocular pressure, perioperative hemodynamics, and anesthetic requirement. Anesthesiology 1988; 68: 707-16.

8 Flacke JW, Bloor BC, Flacke WE et al. Reduced narcotic requirement by clonidine with improved hemodynamic and adrenergic stability in patients undergoing coronary bypass surgery. Anesthesiology 1987; 67: 11-9.

9 Engelman $E$, Lipszyc $M$, Gilbart $E$ et al. Effects of clonidine on anesthetic drug requirements and hemodynamic response during aortic surgery. Anesthesiology 1989; 71: 178-87.

10 Longnecker $D E$. Alpine Anesthesia: can pretreatment with clonidine decrease the peaks and valleys? (Editorial) Anesthesiology 1987; 67: 1-2.

11 Shapiro $H M$. Anesthesia effects upon cerebral blood flow, cerebral metabolism, electroencephalogram, and evoked potentials. In: Miller RD (Ed.). Anesthesia, 2nd ed., New York: Churchill Livingstone Inc.; 1986: 1249-88.

12 Bouloux P, Perrett D, Besser GM. Methodological considerations in the determination of plasma catecholamines by high performance liquid chromatography with electrochemical detection. Ann Clin Biochem 1985; 22: 194-203.

13 Leclerq R, Copinschi G, Franckson JRM. Le dosage par compétition du cortisol plasmatique. Modification de la méthode de Murphy. Revue Française d'Etudes Cliniques et Biologiques 1969; 14: 815-9.

14 Lowenthal DT, Matzek KM, MacGregor TR. Clinical pharmacokinetics of clonidine. Clin Pharmacokinets 1988; 14: 287-310.

15 Ziegler $M G$. Antihypertensive therapie. In: Chernow B (Ed.). The Pharmacological Approach to the Critically Ill Patient. Baltimore: Williams \& Wilkins, 1988; 365-88.

16 Laurito CE, Baughman VL, Becker GL, DeSilava TW, Carranza $C J$. Is clonidine the ideal pre-operative medication? (Abstract) Anesthesiology 1989; 71: A23.

17 Bullington J, Mouton Perry SM, Rigby J et al. The effect 
of advancing age on the sympathetic response to laryngoscopy and tracheal intubation. Anesth Analg 1989; 68: $603-8$.

18 Lanes $R$, Herrera A, Palacios A, Moncada $G$. Decreased secretion of cortisol and ACTH after oral clonidine administration in normal adults. Metabolism 1983; 32: 568-70.

19 Moore RA, McQuay $\dot{H J}$. Neuroendocrinology of the postoperative state. In: Smith G, BG Covino (Eds.). Acute Pain. Stoneham MA, Butterworths, 1985; 133-54.

20 Oyama $T$, Taniguchi $K$, Jin $T$, Satone $T$, Kudo $T$. Effects of anaesthesia and surgery on plasma aldosterone concentration and renin activity in man. $\mathrm{Br} \mathrm{J}$ Anaesth 1979 51: 747-52.

21 Todd MM, Warner DS. Perioperative fluid management in neurosurgery. Current Opinion in Anesthesiology 1989; 2: 559-63.

22 DeFronzo $R A$, Sherwin $R S$, Felig $P$. Synergistic interactions of counterregulatory hormones: a mechanism for stress hyperglycemia. Acta Chirur Scand 1980; 498 (Suppl): 33-41.

23 Metz SA, Halter JB, Robertson RP. Induction of defective insulin secretion and impaired glucose tolerance by clonidine. Selective stimulation of metabolic alphaadrenergic pathways. Diabetes 1978; 27: 554-62.

24 Joffe BI, Haita B, Edelstein D et al. Clonidine and the hormonal response to graded excercise in healthy subjects. Horm Res 1986; 23: 136-41.

25 Sieber FE, Smith DS, Traystman RJ, Wollman H. Glucose: a reevaluation of its intraoperative use. Anesthesiology 1987; 67: 72-81.

26 Kehlet $H$. Modification of responses to surgery by neural blockade: clinical implications. In: Cousins MJ, Bridenbaugh PO (Eds.) Neuronal Blockade in Clinical Anesthesia and Management of Pain. Philadelphia: JB Lippincott, 1988; 145-88.

27 Roizen MF, Horrigan RW, Frazer BM. Anesthetic doses blocking adrenergic (stress) and cardiovascular responses to incision - MAC BAR. Anesthesiology 1981; 54: 390-8.

28 Gelman S, Rivas JE, Erdemir $H$ et al. Hormonal and haemodynamic responses to upper abdominal surgery during isoflurane and balanced anaesthesia. Can Anaesth Soc J 1984; 31: 509-16.

29 Kanawati IS, Yaksh TL, Anderson RE, Marsh RW. Effects of clonidine on cerebral blood flow and the response to arterial $\mathrm{CO}_{2}$. J Cereb Blood Flow Metab 1986; 6: 358-65. 